\title{
Intermédialités
}

Histoire et théorie des arts, des lettres et des techniques

Intermediality

History and Theory of the Arts, Literature and Technologies

\section{"Film-Symphonie vom Leben und Sterben der Blumen": Plant Rhythm and Time-Lapse Vision in Das Blumenwunder}

\section{Janelle Blankenship}

Numéro 16, automne 2010

rythmer

rhythmize

URI : https://id.erudit.org/iderudit/1001957ar

DOI : https://doi.org/10.7202/1001957ar

Aller au sommaire du numéro

Éditeur(s)

Revue intermédialités (Presses de l’Université de Montréal)

ISSN

1705-8546 (imprimé)

1920-3136 (numérique)

Découvrir la revue

Citer cet article

Blankenship, J. (2010). "Film-Symphonie vom Leben und Sterben der Blumen": Plant Rhythm and Time-Lapse Vision in Das Blumenwunder. Intermédialités /

Intermediality, (16), 83-103. https://doi.org/10.7202/1001957ar
Résumé de l'article

Cet article analyse la cinématographie d'images en accéléré pratiquée au début du $20^{\mathrm{e}}$ siècle afin de démontrer comment les nouveaux mondes dès lors accessibles par de telles images ont influencé certains biologistes, comme Jakob von Uexküll, et théoriciens de l'avant-garde des années 1920. À partir du « film culturel » allemand Das Blumenwunder (Le miracle des fleurs, 1926), l'auteur examine la manière dont le film cherche à traduire le " rythme intérieur » des plantes, une temporalité qui contesterait une conception anthropocentrique du monde tout en s'accordant aux rythmes extatiques de la danse moderne. L'auteur discute de l'usage auto-réflexif de la technologie d'images en accéléré, de l'histoire de sa réception au sein de l'avant-garde et de la réforme pédagogique, ainsi que de l'utilisation spécifique de la chorégraphie d'Ausdruckstanz pour créer une nouvelle forme mimétique d'affect en réponse aux rythmes industriels de l'époque. 


\title{
"Film-Symphonie vom Leben und Sterben der Blumen": Plant Rhythm and Time-Lapse Vision in Das Blumenwunder
}

\author{
Janelle Blankenship
}

ne of the most recurrent tropes in the reception of early cinema had to do with its ability to reveal worlds of experience hitherto closed to the human eye. Whether through images of microcinematography or through timelapse photography, film theorists often commented on the sense-as Béla Balázs would later describe it in a discussion of early scientific films - of entering a "territory closed to man." Walter Benjamin, similarly, described the experience of watching Karl Blossfeldt's enlarged plant photographs as an irruption of another order of visual experience into the everyday: "Whether we accelerate the growth of a plant through time-lapse photography or show its form in forty-fold enlargement, in either case a geyser of new image-worlds hisses up at points in our existence where we would least have thought them possible." ${ }^{2}$

Such sentiments, however, hardly began with the modernist film theorists of the 1920 . Already at the beginning of the $20^{\text {th }}$ century, the German biologist Jakob von Uexküll-inspired by the 186 os media fantasies of Estonian embryologist Karl von Baer (author of "Which View of Living Nature is Correct?") 3 and the film experiments of chronophotographer Étienne-Jules Marey-argued that

1. Béla Balázs, Theory of the Film. Character and Growth of a New Art [1952], trans. Edith Bone, New York, Arno Press, 1970, p. 173.

2. Walter Benjamin, "News about Flowers" in Walter Benjamin, Selected Writings, vol. 2, trans. Michael W. Jennings, Cambridge (Mass.), Harvard University Press, 2001, p. 156 .

3. Karl Ernst von Baer, "Welche Auffassung der lebenden Natur ist die richtige? und wie ist die Auffassung auf die Entomologie anzuwenden?," Horae Societatis Entomologicae 
the biologist as film experimenter must also become a semiotician and grasp the "world" of the animal through a new vision, taking his or her cues from the perspective and vision of the animal alone:

Our anthropocentric way of looking at things must retreat further and further, and the standpoint of the animal alone must remain. When this occurs, everything that we hold as self-evident disappears: all of nature, earth, heaven, stars, indeed, all the objects that surround us $[\ldots]$. A new world takes shape around every animal, completely different from our own: its Umwelt. ${ }^{4}$

If animal and plant perception fail our "short sighted eyes," as von Uexküll argues in multiple essays and manifestos from Biologische Briefe an eine Dame (Biological Letters to a Lady, 1920) ${ }^{5}$ to Theoretical Biology (1926), ${ }^{6}$ putting nature itself under the spell of slow motion or time-lapse lens is seen as a "corrective"-a utopic view and alternative modernity first articulated by magic lantern showmen and microscopy manuals in the late $19^{\text {th }}$ century. ${ }^{7}$

The cinema, according to von Uexküll, was uniquely poised_as Ernst Mach had already argued in the 188os-to "picture" the development of a species, or accelerate or condense time, in an approximation of animal or plant temporality. Von Uexküll famously argued that cinema can heighten our power of visualization, drawing an analogy between the development of a species and time-lapse blossoming and fading of flowers:

In this way it is possible to reduce to a form that can be visualized the series of recurrent changes in the species. This form resembles a plant, the stem of which, by

Rossicae, Petersburg, vol. 1, 1861, p. 1-45. Von Baer's address was delivered at the opening of the Russian Entomological Society in May 1860.

4. Jakob von Uexküll, Umwelt und Innenwelt der Tiere, Berlin, Verlag von Julius Springer, 1909, p. 6, (my translation). For a more detailed account of von Uexküll's influential notion of Umwelt, see Geoffrey Winthrop-Young, "Bubbles and Webs: A Backdoor Stroll through the Readings of Uexküll," afterword to Jakob von Uexküll, A Foray into the Worlds of Animals and Humans, trans. Joseph O'Neal, Minneapolis, University of Minnesota Press, 2010, p. 209-243.

5. Jakob von Uexküll, Biologische Briefe an eine Dame, Berlin, Verlag von Gebrüder Paetel, 1920.

6. Jakob von Uexküll, Theoretical Biology, trans. D. L. MacKinnon, London, Kegan Paul, Trench, Trubner and Co.,1926

7. Numerous theorists and practitioners of microscopy and optical projection in the $19^{\text {th }}$ century heralded the microscope's magnifying gaze as an emancipatory vision no longer "walled in" by the "bricks and mortar" of the metropolis. See William Carpenter Benjamin, The Microscope and its Revelations [1856], New York, William Wood, 1883. 
rhythmical repetition, gives off shoots; of these a great portion come to naught, but the remainder unite again to form a new stem. The greater our powers of visualisation, the better able shall we be to make this picture richer in detail and more true to Nature. We can also think of this coming into being and then dying away as though it took place cinematographically; then we participate in the rhythm, and so get the right impression of the species as a rhythmical sequence of acts."

Here, von Uexküll draws upon the cinematograph as a thought experiment to emphasize the importance of participating (mitempfinden) in the "rhythm of the species." In von Uexküll's semiotic code, one is simultaneously observer/ spectator and actor. Although primarily concerned with charting out the interior world or Umwelt of animals, von Uexküll also hails plants as sentient beings, "animated life forms" in continuous movement. Plant subjects and rhythm for von Uexküll unfold as a lyrical melody of Ich-Impulse ("Ego-Impulses"):

Since plants are not dead structures [Gehäuse], but rather live their lives continuously, we recognize in them a vital rhythm, parallel to the alternation of the seasons. [...] [T] he inner rhythm of plants, however, is adapted much more closely to seasonal change. [...] The formal developments of plants show the melody of impulses more clearly than animals. ${ }^{9}$

As von Uexküll invites us to "stroll into unfamiliar worlds," time itself is estranged: "the subject sways the time" of his or her "own world" as the biologist states in an illustrated picture book. The biologist celebrates nature's design, depicting it as a melodious movement, for example, comparing the genes in a fertilized egg to the keys on a piano, upon which "formative melodies" may be played. Transcribing Karl von Baer's ideas on time and relativity, ${ }^{10}$ von Uexküll in his popular biology seeks to illuminate the "inner rhythm" of the natural world, perfecting our view of its wonders. He envisions an alternate universe, contemplating how nature would appear if one lengthened or shortened the human minute:

8. Von Uexküll, 1926, p. 245, (my emphasis).

9. Jakob von Uexküll, Kompositionslehre der Natur: Biologie als undogmatischer Naturwissenschaften, ed. Thure von Uexküll, Frankfurt am Main, Berlin and Wien, Verlag Ullstein GmbH, 1980, p. 209-210.

10. See Karl von Baer's fantasy of the "Minutenmensch" ("Which View of Nature is Correct"?) or his 1864 lecture, "Die Abhängigkeit unseres Weltbildes von der Länge unseres Moments," excerpt reprinted in Grundlagenstudien aus Kybernetik und Geisteswissenschaft, Beiheft, vol. 3, 1962, p. 251-275. 
$[\ldots]$ the sun, whose forward gliding is, as things are, imperceptible to our eyes, would acquire colossal speed in order to cover, in the same length of time, the vast span of the heavens. The shadows of the giant trees would be in perpetual movement. The movement of all living objects would seem to us to be accelerated; even the snails would hurry by at the speed of a trotting horse, and we ourselves would move about through this monstrous space as fast as express trains. Assuming, on the other hand, that the moments correspondingly shortened, then all movements would remain of normal size, but for their execution the day would stretch out to excessive length, and soon we should no longer be able to cope with the strain imposed by this super-world. ${ }^{11}$

The "human moment"-initially defined as the pulse rate, part of the inner rhythm of our central nervous system, or the time it takes to register a sensory impression-can be expanded or contracted in a lyrical play on relativity. ${ }^{12}$ As early as 1860, photographers and scientists recognized the relativity of time and space and quarreled over how to precisely define an "Augenblick" (moment, blink of an eye) just as they would later debate the trajectory of the flight of a bird, bullet, or light. Von Uexküll (who had studied chronophotography with the "master," Étienne-Jules Marey) is equally invested in photographic and filmic discourses on temporality and Karl Ernst von Baer's theory that "time is the product of a subject." Although the semiotician does not subscribe to the Darwinian reduction of living beings to "mere machines," ${ }^{3}$ he mobilizes machinic Hilfsmittel (media aids) and perceptual tools to "visualize" nature's interior:

$[\mathrm{T}]$ ime is the product of a subject. Time as a succession of moments varies from one Umwelt to another, according to the number of moments experienced by different subjects within the same space of time. [...] Kinematography projects environmental motion onto a screen at their accustomed tempo. The single pictures follow each other in jerks of $1 / 18$ second. If we wish to observe motion too swift for the human eye, we resort to slow-motion photography [...] Processes too swift for our human tempo (18 per second), such as wing-beat of birds and insects can be made visible.

11. Von Uexküll, 1926, p. 68.

12. Von Uexküll writes, "Wir nennen Moment jene Spanne Zeit, die ein Lebewesen verwendet, um äussere Eindrücke als gleichzeitiges Merkmal aufzunehmen. Die Ursache hierzu liegt in einem inneren Rhythmus des Zentralnervensystems," in von Uexküll, 1980, p. 198. Karl von Baer famously wrote that the pulse stands in direct relation to the perceived speed of movements and sensations: "Überhaupt scheint der Puls in gewisser Beziehung mit der Schnelligkeit von Empfindung und Bewegung zu stehen.” Baer, 1861, p. 2.

13. Jakob von Uexküll, "Stroll through the Worlds of Animals and Men: A Picture Book of Indivisible Worlds," in Instinctive Behavior: The Development of a Modern Concept, trans. and ed. Claire Shiller, New York, International Universities Press, 1934, p. 7. 
As slow-motion photography slows motor processes down, the time contractor (timelapse) speeds them up. If a process is photographed once an hour and then projected at the rate of $1 / 18$ a second, it is condensed into a short space of time. In this way, processes too slow for our human tempo, such as the blossoming of a flower, can be brought within range of our perception. ${ }^{14}$

Von Uexküll is not alone in the early $20^{\text {th }}$ century in appropriating both musical terms and motion picture technology to forge a new discourse on timelapse, perception and life rhythm. As Malin Wahlberg has noted in an essay on the aesthetic experience of scientific film, the emphasis on rhythm as "measured interval" and "sensory pulse-beat" also corresponds with "contemporaneous ideas and new developments in $20^{\text {th }}$ century phenomenology and psychoanalysis." 15 Perhaps this is nowhere more evident than in the avant-garde film theory of Germaine Dulac. Time-lapse was instrumental to Dulac's notion of an "integral cinema," in which the development of lines, surfaces and volumes "dispossessed of any overly human sense" would allow "an elevation towards the abstract." ${ }^{16}$ In terms reminiscent of von Uexküll, she described the sight of plant movement as one of participation in other rhythms:

A grain of wheat sprouts; it is synthetically, again, that we judge its growth. Cinema, by decomposing movement, makes us see, analytically, the beauty of the leap in a series of minor rhythms which accomplish the major rhythm, and, if we look at the sprouting grain, thanks to film, we will no longer have only the synthesis of the moment of growth, but the psychology of this movement. We feel, visually, the painful effort a stalk expends in coming out of the ground and blooming. The cinema makes us spectators of its bursts toward light and air, by capturing its unconscious, instinctive and mechanical movements. ${ }^{17}$

No longer is cinema as analysis (decomposition) opposed to the more classical notion of cinema as synthesis (the famous opposition drawn by ÉtienneJules Marey). Dulac holds that time-lapse spectators witness both major and minor rhythms, synthesis and decomposition. On the one hand, spectators observe the overarching "synthesis" of the Circadian growth patterns ("major rhythm”), yet time-lapse spectators are also trained to read the psychology of plant

14. Ibid., p. 25, (translation modified).

15. Malin Wahlberg, "Wonders of Cinematic Abstraction: J. C. Mol and the Aesthetic Experience of Science Film," Screen, vol. 47, $n^{\circ}$ 3, 2006, p. 278.

16. Program notes of Germaine Dulac's Thèmes et Variations (1928).

17. Germaine Dulac, "Visual and Anti-Visual Films," trans. Robert Lamberton, in P. Adams Sitney (ed.), The Avant-Garde Film: A Reader of Theory and Criticism, New York, Anthology Film Archives, 1987, p. 32. 
movement, nature's "optical unconscious" or ecstatic "minor rhythms" that burst onto the screen. Similar to von Uexküll, Dulac sees time-lapse as a tool to "give voice, laughter and tears" to "inanimate objects," to use rhythm and movement to awaken affect, emotion and conjure up a "new world" of plant temperament.

Avant-garde theorists and writers in the 1920 s were haunted by the climbing tendrils of time-lapse, even writing that children during screenings were compelled to "perform" plant temperament and movement. In an essay entitled "The Cinema," the French author Sidonie-Gabrielle Colette in 1920 speaks powerfully of the effect time-lapse footage had on audiences at the Musée Galliera:

A "fast motion" documentary documented the germination of a bean [...] At the revelation of the intentional and intelligent movement of the plant, I saw children get up, imitate the extraordinary ascent of a plant climbing in a spiral, avoiding an obstacle, groping over its trellis: "It's looking for something! It's looking for something!" cried a little boy, profoundly affected. He dreamt of a plant that night, and so did I. These spectacles are never forgotten... ${ }^{18}$

For Jean Epstein, such films exemplified a new kind of cinema, in which time would conquer space:

Slow motion and fast motion reveal a world where the kingdoms of nature know no boundaries. Everything is alive. Crystals become larger, growing one on top of another $[\ldots]$. And the plant which bends its stalk and turns its leaves toward the light; isn't what opens and closes its corolla, what inclines its stamen to the pistil, in fast motion, precisely the same quality of life in the horse and rider which, in slow motion, soar over the obstacle, pressing close to one another? ${ }^{19}$

Epstein argues that time-lapse is a "rhythmic, poetic, photogenic effect," a cadence that the camera can read "better than the human eye and by other means."

One could extend such analyses of the ways in which cinema was understood as a means for accessing inhuman rhythms and temporalities to countless other examples - from the notion of time-lapse as a window onto "the fourth dimension" in the work of French biophysicist and philosopher Pierre Lecomte de Noüy

18. Sidonie-Gabrielle Colette, "The Cinema," in Alain and Odette Virmaux (eds.), Colette at the Movies: Criticism and Screenplays, trans. Sarah W. R. Smith, New York, Frederick Ungar, 1980, p. 61.

19. Jean Epstein, "Photogenie and the Imponderable," in Richard Abel (ed.), French Film Theory and Criticism: A History/Anthology, 1929-1939, vol. 2, Princeton, Princeton University Press, 1988, p. 189-190. 
and the surgeon and biologist Alexis Carrel $^{20}$ to the project of cultivating a "new vision" among artistic spectators in the work of László Moholy-Nagy and Walter Benjamin in the 1920 and 1930 . $^{21}$ In what follows, however, I wish to examine how the Weimar Kulturfilm dialogues with this discourse on time-lapse and "life rhythms," using as my primary case study the 1926 Unterrichts-Film-Gesellschaft production, Das Blumenwunder (Miracle of Flowers), a feature-length time-lapse spectacle screened at the Bauhaus in Dessau in 1927. ${ }^{22}$ Sponsored by the chemical corporation BASF (Badische Soda and Anilin Factory), Das Blumenwunder-a hybrid of "Kulturfilm" and "Lehrfilm" (instructional film) - set out an almost impossible task, to give time-lapse cinematography a "feature length" run. ${ }^{23} \mathrm{~A}$ new spin on the art of macroprojection, the "film symphony of the life and death of flowers" premiered on February $25^{\text {th }}$, 1926 in Berlin's Piccadilly-Theater with an original music score and elaborate frame narrative. If the "blossoming of flowers" served primarily as documentary in the early $20^{\text {th }}$ century, as biologist Alexis Carrel reminds us, evoking the science fiction of H.G. Wells, the topic also lent itself to far-fetched fantasy. Fantasy is also what sets the 1926 Unterrichts-FilmGesellschaft motion picture Das Blumenwunder apart from other time-lapse releases of the 1920s. The same year marked the release of another feature-length nature film directed by Wolfram Junghans for Kulturfilm-AG, Die Biene Maja und Ihre Abenteuer, an adaptation of a popular children's book, with a live insect

20. See Pierre Lecomte de Noüy, Biological Time, New York, Macmillan, 1937, p. 7.

21. See Walter Benjamin, "Small History of Photography," in Benjamin, 2001, p. $510-512$.

22. "Film im Bauhaus", Film-Kurier, n 66, March 18, 1927. See also another avantgarde treatise on nature, the April 1924 issue of the Dada journal MERZ. In bold typography the editors El Lissitzky and Kurt Schwitters pronounce "Es ist GENUG immer MASCHINE MASCHINE MASCHINE. Die Maschine hat uns nicht von der Natur getrennt. Durch sie haben wir eine neue, vorher nicht geahnte Natur entdeckt [...] Die moderne Welt ist die andere Hälfte der Natur, die aus dem Menschen wächst." Using a language evocative of time-lapse photography, MERZ depicts machinic modernity as lyrically "blossoming" or unfolding out of the human body.

23. At both the Berlin premiere and the Bauhaus screening in Dessau in 1927, the film met with "unlimited applause." See Jeanpaul Goergen, "Neues Sehen im Zeitraffer. DAS BLUMENWUNDER (1926)," Filmblatt, vol. 9, n²4, Spring-Summer 2004, p. 41-44, and "Aus einem Brief von Eduard Künneke an Franz Marszalek, 31. März 1951: Die beste Filmmusik...," Filmblatt, vol. 9, n²4, Spring-Summer 2004, p. 46-47. 

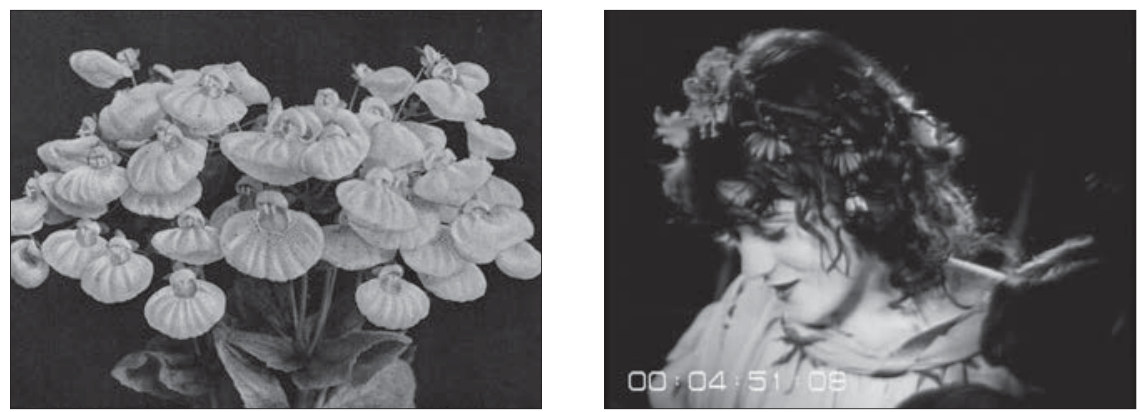

Fig. 1: Slipper Flower. Das Blumenwunder Souvenir Program (Private Collection).

Fig. 2: Flora (Maria Solveg). Das Blumenwunder (Bundesarchiv-Filmarchiv).

cast and expressionist Bienenschloss designed by Albin Grau (set designer for Murnau's Nosferatu and founder of the short-lived film company Prana Film). ${ }^{24}$

Das Blumenwunder made its mark on German audiences as a new and innovative Gross-Kulturfilm. Many critics raved at the appearance of the film's new star, "time-lapse cinematography" and also praised the film's Metropolis-like frame narrative featuring a plant fairy named "Flora", played by Maria Solveg (Fig.1 and 2). Others complained that time-lapse had exceeded its parameters. In a 1926 article in the journal Lehrfilm entitled "Kulturfilm oder Lehrfilm: Kritische Beobachtungen zum Blumenwunder," a doctor argued that the film material could only be salvaged if it were pulled from the theaters and screened in schools, which in his words "are screaming for such material." 25 The Lehrfilm reviewer asserted that the film's main merit is its ability to instruct, not disseminate culture. The time-lapse life and interior rhythm of plants, introduced and translated for children in the film's framing narrative, is seen as perfect pedagogy, more effective than "punitive measures such as disciplinary warnings or violent slaps" in training children not to use their "raw hands" to pluck "innocent living beings." This critic argues that the film could be used in the schools to cultivate an ethical and aesthetic awareness, a new "love for nature" and perhaps even a Biblical "love for one's neighbor."

24. Blumenwunder was part of a larger cycle of Gross-Kulturfilme, including Die Biene Maja and Natur und Liebe: Schöpferin Natur (both released in 1926).

25. Dr. M-l, "Kultur-oder Lehrfilm? Kritische Betrachtungen zum 'Blumenwunder," Der Lehrfilm: Beilage zu "Der Filmspiegel" (Kinematographische Monatshefte), Berlin, July 1926, p. 22.

26. Ibid. 
Responding to the film's hybrid genre and framing narrative, the Lehrfilm critic argues that the film effectively demonstrates that the children of Flora also have life, emotions even a certain kind of consciousness, but he laments the lack of intertitles that would classify plant genus and species. The same author harshly critiques the expressionist "Kulturfilm" leanings inherent in the timelapse production, writing that "it came about that the beautiful, artistically ideal, modest and unpretentious nature is imported into a blossoming kitsch of unnatural and forced dances by above all, ugly people."27 Particularly onerous for this reviewer is not only the narrative frame with the fairy Flora which leads into the time-lapse footage, but also the ballet and expressionist dance scenes, intercut with time-lapse footage throughout the film, where human actors "respond to" or mimic nature's moods. The expressionist dance form as ugly distortion is seen as an artificial contamination of the film's documentary value. The critic thus touts the "Lehrfilm" instructional film potential and rejects the "Kulturfilm" leanings inherent in this time-lapse production.

In sharp contrast to the educator in Lehrfilm, the prolific reviewer and art film enthusiast Fritz Olimsky argued that the interpretive dances and modern ballet by members of the Berlin State Ballet Corps developed harmoniously out of the natural blossoming pictures, enabling a deep look into the "psyche of plants":

This film offers deep insights into the psyche of plants, such as our greatest poets could hardly have dreamt of. It was a good idea to heighten the effect of this miracle of blossoms in a subtle way by means of first-class dances from our Staatsoper. And we should emphasize in particular how successfully the film develops these dances harmoniously out of the images of natural blossoming. ${ }^{28}$

Rudolf Arnheim echoes Olimsky in Film as Art, also arguing that the timelapse spectacle Das Blumenwunder is the most "exciting, fantastic and beautiful film ever shot." ${ }^{29}$ Arnheim argues that time-lapse is not only an effective vehicle for transmitting the hectic tempo of modern streets and industrialization; it also offers a glimpse into the rhythmic breathing of a previously unknown "interior world." Arnheim celebrates the "expressive gestures," "excited dance" and

27. Ibid., p. 24 .

28. Fritz Olimsky, “Neue Filme. Das Blumenwunder," Stiftung Deutsche Kinemathek, Schriftgut File "Blumenwunder."

29. Rudolf Arnheim, Film as Art [1932], Berkeley, University of California Press, 2006, p. 136. 
"abandon" of the rhythmic leaves and flowers, arguing that nature itself is already “expressive," a perfect partner to Ausdruckstanz itself:

The swaying rhythmic breathing motions of the leaves, the excited dance of the leaves around the blossom, the almost voluptuous abandon with which the flower opensthe plants all at once come alive and show that they use expressive gestures like those to which we are accustomed in men and animals. Watching a climbing plant anxiously groping, uncertainly seeking a hold, as its tendrils twine around a trellis, or a fading cactus bloom bowing its head and collapsing almost with a sigh, was an uncanny discovery of a new living world in a sphere in which one had of course always admitted life existed but had never been able to see it in action. Plants were suddenly and visibly enrolled in the ranks of living beings. One saw that the same principles applied to everything, the same code of behavior, the same difficulties, the same desires. ${ }^{30}$

Not surprisingly, authors of German Expressionism also praised the film for its ability to unlock the "tempo" of the natural (even: supernatural) world. The German expressionist author Oskar Loerke wrote in his diary entry of March $7^{\text {th }}$, 1926 that the film "proved all that is supernatural":

Yesterday I saw the film Das Blumenwunder with Bäumchen (Clara Westphal) and Kropff. It was a first-class experience. Unbelievable. The film nearly proves the existence of everything supernatural. When one sees the growth and life of plants that have another tempo from that of people, every order becomes imaginableeven slower tempos or faster ones, which are not perceptible to us because of this difference. ${ }^{31}$

Other modernist authors made explicit connections to a Bergsonian vitalism. ${ }^{32}$ The German Expressionist and journalist Kurt Pinthus celebrated the film as a monument to the continuous "becoming of elan vital." Reading into the Daseinskraft and vital force of time-lapse, Pinthus sees not only "lust for life" and erotic struggles; he also stamps each species in Blumenwunder with its own distinct rhythmical movement: "one recognizes that the unfolding always occurs in a rhythmical movement and that these gestures of nature are the same in one individual species but differ in all other species." Some flowers are seen to

\section{Ibid.}

31. Oskar Loerke, Tagebücher 1903-1939, ed. Hermann Kasack, Heidelberg and Darmstadt, Verlag Lambert Schneider, 1956, p. 137.

32. Such an oscillation between occultism and vitalism is less surprising, if one recalls that at the turn-of-the-century Bergson and Étienne-Jules Marey investigated the rhythms of the supernatural during a series of séances held at the Collège de France. Ernst Mach also studied supernatural phenomena. 
nod their heads "like old women," others appear to slide like ocean "polyps." Although the critic finds the "grace" of the choreographed anthropomorphic "interpretations" of the plants "far inferior to the grace of the flowers themselves," this doesn't dampen his overall enthusiasm for the film. Pinthus ends his review on a pedagogical note, like the Lehrfilm critic, arguing for the mass appeal of the film, urging Germany's cultural minister to "purchase the film with federal funds" and provide it free of charge for schools and public performances, arguing that mother and child, dignified old men, the church and theatre, schools and universities should be able to "see with their own eyes" what the philosophers and scientists had failed to put into words, "the most secret and natural wonder of the world." ${ }^{33}$

International educational organizations and authors also took special note of the film. Blumenwunder was promoted by the League of Nations, ${ }^{34}$ screened in England at a social meeting of the Anglo-German Academic Bureau at the University of London, University College, ${ }^{35}$ and praised by Welsh writer and novelist Berta Ruck, among others. The film was also a "special sightseeing attraction" at an "expo-cinema" during the 1927 horticulture congress in Leipzig, and was screened as a horticultural film at a monthly meeting of the garden club "Verein zur Beförderung des Gartenbaues in den königlich preussischen Staaten, Deutsche Gartenbau-Gesellschaft" in $1926 .{ }^{36}$

33. Kurt Pinthus, "Das Blumenwunder," Das Tagebuch, vol. 7, n² 2, 1926, p. 974.

34. The first board of directors of the League of Nation's "International Institute for Educational Cinematography" included Hans Curlis, director of the German "Institut für Kulturforschung" and Louis Lumière; Henri Bergson and Rudolf Arnheim were also affiliated with the institute, and artists Moholy-Nagy and Germaine Dulac contributed to the institute's journal. In a 1931 issue of the institute's International Review of Educational Cinematography, the German critic Erwin W. Nack praised Blumenwunder's appeal for mass audiences: "The Miracle of Flowers, produced six years ago, demonstrated that the public could never see enough of these plant-films, which simple though they are, have a fascinating and even exciting attraction. Every year, and in the hot weather, too, when the cinemas are generally half empty, this film exercised irresistible drawing power." See Erwin Wolfgang Nack, "Mysteries of Plant Life on the Screen," Interciné: International Review of Educational Cinematography, vol. 13, 1931, p. 636-668.

35. The Anglo-German Academic Bureau (London) also purchased a copy of the film in 1931, which they made available to the public, along with multiple "slide sets dealing with Germany on subjects of general interest." See "Lantern Slides and Films on Germany,"Journal of Education: A Monthly Record and Review, vol. 63, 1931, p. 571.

36. Gartenflora: Zeitschrift für Garten- und Blumenkunde, vol. 75, 1926, p. 189. 
Not surprisingly, the film's time-lapse poetry of plant rhythm, intercut with Ausdruckstanz, resonated with reform pedagogy and the avant-garde alike. The film's "kinetic poetry" no doubt spoke to Bauhaus artists who embraced timelapse images of nature as a "raw stimulus" and a "new education in materials." Moholy-Nagy in the 1920s asserted that technical developments in photography and film enabled a "new vision," which would provide a "new education in materials" and an important "stimulus to a more leisurely observation of the object itself." ${ }^{37}$ Bauhaus instructors and their contemporaries, such as utopian architect Bruno Taut, embraced the educational quality of time-lapse documents of the growth processes of plants or crystals, arguing that time-lapse films "engender artistic fantasy." ${ }^{38}$ Blumenwunder also inspired leaders in the field of "Musikalische Graphik," a pedagogical reform movement on musical language. In 1932, at a Viennese conference entitled "20 Jahre Musikalische Graphik," Berta Ernst used the film as a model in an experimental classroom on rhythm, on the melodious "form of nature." The conference featured two experimental classrooms exhibiting the newest trends in art pedagogy. According to the conference program notes, Ernst's session with her "fourth class" had a particular focus on musical language; she invited students to perform the "flowing rhythm of a cyclamen" or the "proud pose of a lily blossom, as presented in the Urania time-lapse film Das Blumenwunder, which makes the gestural language of plants visible." A. Klimisch's experimental classroom had a similar topic aimed at a younger age group, "capturing different life-rhythms: the beating of the pulse, breathing, walking." ${ }^{39}$ Here the starting point for the examination of physiological and natural "life rhythms" is the body's own interior, similar to Blumenwunder itself, which initially catalogues micro-cinematographic shots of a girl's pulse, in its meditation on alternative life rhythms.

In Hans Richter's celebration of the avant-garde's new vision in his treatise Filmgegner von heute, Filmfreund von morgen, a Blumenwunder frame enlargement also appears as raw and expressive stimulus in a montage celebrating

37. László Moholy-Nagy, The New Vision: From Material to Architecture [1928], trans. Daphne M. Hoffman, New York, Wittenborn, Schultz, 1967, p. 26.

38. As cited in Regine Prange, Das Kristalline als Kunstsymbol: Bruno Taut und Paul Klee. Zur Reflexion des Abstrakten in Kunst und Kunsttheorie der Moderne, Hildescheim, Georg Olms, 1991, p. 133.

39. "Festhalten verschiedener Lebensrhythmen: Klopfen des Blutes, Atmen, Gehen," Führer durch die Ausstellung 20 Jahre Musikalische Graphik. Kunstpsychologische Versuche aus dem Gebiete der FarbeTonforschung, hektographiert, Wien, Kunstlerbund Hagen, 1934 . 
the "new beauty" of scientific techniques including microcinematography. ${ }^{40}$ Blumenwunder's elaborate "souvenir program," printed on Japanese paper, similarly speaks of the film's new "Schönheitswerten" (aesthetic beauty and value), informing the audience that the directors are not botanical experts and do not want to interpret the plant's secretive, dream-like choreography. They simply wish to teach spectators "how to see":

We are not botanists. We do not draw any consequences from these mysterious, dreamlike movements of dance. We only wish to show them to you! But one thing is certain! This flickering song of blossoming and wilting moves our most interior being. Our eyes learn to see. ${ }^{41}$

Even in its graphic design, the program celebrates the power of film as an avant-garde vision, featuring a vertical strip of images arranged in a manner to imitate the vertical rhythm of frames on a film strip. Sprocket-less strips are placed at the centre and also on the outer edge of each page of the program, almost evocative of a "flip book." In a manner befitting the fairy-tale appearance of Willy Petzold's colorful sketch of the fairy Flora, used on the cover of the program and on posters advertising the film's premiere, the program cultivates a special language of technical miracles and mysteries. The program immediately divulges "the film's secret," alerting the spectator to the fact that the film began as an industrial/advertising picture, sponsored by the Badische Anilin-und-Sodafabrik, a factory that wanted to sell farmer's nitrogen as fertilizer. But the program soon leaves advertising and industrial rhythms behind, teaching spectators to measure the perception of time in different organisms. As the official program explains "The Aladdin lamp (Wunderlampe) of cinema thus made it possible to adjust our eyes to another life rhythm, the life rhythm of plants." Plant frame enlargements and enlarged stills of expressionist dance performances taken from the film enhance its sensational narrative of time-lapse motion picture technology. The program ends by celebrating the aesthetic effect of time-lapse. Although the program notes are silent on Blumenwunder's use of Ausdruckstanz, the highly emotional choreography is another visual attempt to translate the struggles and goals of the plant psyche: "One cannot describe these movements, this searching, struggling and grasping of climbing plants, the cramp-like movements of buds

40. Hans Richter, Filmgegner von heute-Filmfreunde von Morgen [1929], Frankfurt am Main, Fischer, 1981.

41. Das Blumenwunder, Souvenir Program, Unterrichtsfilmgesellschaft, 1925, (private collection). 

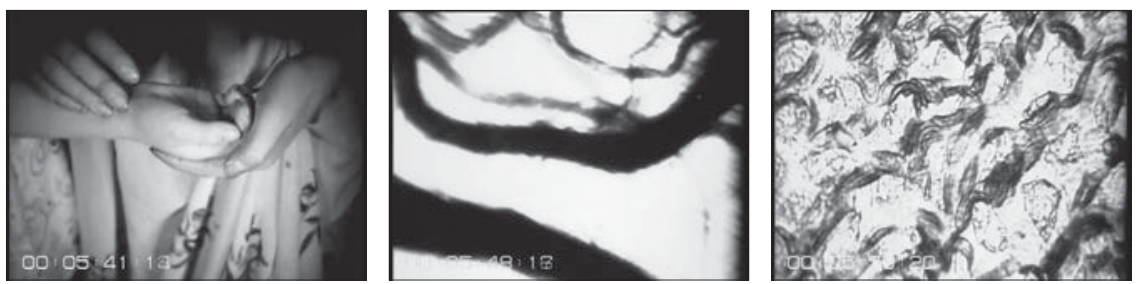

Fig. 3 a, b, c: Life-Rhythm, Human Pulse, and Blood Pictures. Das Blumenwunder (BundesarchivFilmarchiv).

before their unfolding, the death-woes of flowers. Written language has no words for it."

Like the pleasure garden of Metropolis (1927), where a walking specter Maria enters the frame to teach the sons of the lives and rhythms and temporalities of those less fortunate below, Das Blumenwunder also speaks of a life hovering beyond human perception and awareness. Flora first admonishes the children for plucking innocent flowers: "You do not notice their sorrows and struggles, because the rhythm of their movement operates under a different time measurement, and yet like you they flower and fade." Prior to the film's spectacle of timelapse picture projection, Flora grabs a girl's wrist to cinematically take her pulse and project "blood pictures" pulse and life rhythm of the plant world. Before the plant world can be mapped and deciphered, it is the human body itself that has to be read, estranged, made uncanny, through this vivid look into the interior. In a pivotal moment in the film's pedagogy, a didactic intertitle points to the "pulse beat as the human second": "The life rhythm of the human is the pulse, is the swaying of the blood corpuscles" and "[a] pulse beat is the human second" (Fig.3a-3c).

As the sequence on human and plant temporality continues, microcinematography and time-lapse photography work in tandem. A zoom brings the girl's wrist progressively closer to the spectator. To visualize the human pulse (translated for the child spectator as the basic unit of "human temporality"), the close-up of the child's wrist dissolves into a micro-cinematographic shot of blood corpuscles. The camera then penetrates closer into the interiority of the body, projecting an extreme high-speed micro-cinematographic shot of cells in continuous flow of blood plasma. As Flora continues her plant parable, the camera cuts to a clock, turning from physiological time and the flow of the body's interior to physical time, depicting the exterior manifestation or measure of the

42. "Microkinematography," Nature, $n^{\circ} 88$, December $14^{\text {th }} 1911$, p. 214. 

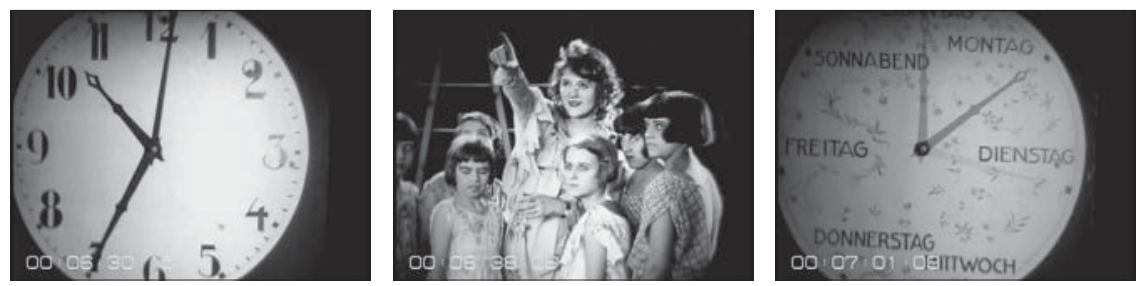

Fig. 4 a, b, c: Plant Temporality: "Let the clock race!" Das Blumenwunder (Bundesarchiv-Filmarchiv).

human second, the mechanical movement of the clock. In a scientific, objective rendering of the second as basic measure of "human time" (here an external measure of the internal beat of the human pulse, as Karl von Baer argued in the mid-19 $9^{\text {th }}$ century), the diurnal clock crawls along uniformly in real time. But suddenly our understanding of temporality is turned on its head, estranged, as Flora announces: "Let the clock race!" The clock's second and minute hand are all but obscured in the play of extreme high-speed cinematography. This first clock-an objective marker of "mechanical time"-gradually fades, dissolving into a more impressionist time-piece, decorated with tendrils and leaves (themselves echoing the plant motifs on Flora's gown), representative of a shift to plant temporality (Fig. 4a-4c). The dissolve into a new timepiece also foreshadows the film's later dissolves, from time-lapse footage into expressionist dance. The timelapse clock is not a symbol of accelerated industrial rhythm or a system in crisis, like the clocks in Fritz Lang's M (1931) or Metropolis. The hyper-movement and dissolve into a new timepiece indicates the need to move beyond the "externality" and objectivity of a staccato measure, to heed the multiplicity of plant's own internal "life rhythms." Flora's plant parable echoes von Uexküll's biological call to heed the inner life cadences of the natural world. Seconds and minutes are effaced and in their place we find the days of the week. This dissolve between the two clocks sets the stage for the technological wonder of time-lapse, itself a compression of four years (of growth) into one hour of screen time, also marking the transition from human to "plant temporality." The ornamental clock in Blumenwunder, radically unlike the stark grid and racing chronometer of "efficiency" in Frank and Lillian Gilbreth's time-motion study films (which at least gives one the "impression of scienticity"), ${ }^{43}$ does not showcase scientific

43. See Scott Curtis, "Images of Efficiency: The Films of Frank B. Gilbreth," in Vinzenz Hediger and Patrick Vonderau (ed.), Films that Work: Industrial Film and the Productivity of Media, Amsterdam, Amsterdam University Press, 2009, p. 85-99. 
objectivity and uniformity, but rather points to nature's alterity. The plant clock has a variable tempo; it slows down and accelerates, translating subjective plant rhythms into a human calendar of weeks and months. Flora in her function as inner-diegetic narrator announces the trip into time-lapse photography: "Twenty four hours, a day in the life of humans, is a second in the life of flowers [...]. And now look! Transfixed in time lapse, your eyes will begin to see!" In the first act's final shots, we see the surprised faces of the child spectators, several with heavilymade up expressionist eyes, with bodies that sway and move in rhythm with the plants, anticipating the interpretive dance to come. Reminiscent of von Uexküll's popular biology, the spectator is called upon to "participate" in the rhythm of the species. Several girls blink incessantly, perhaps a self-reflexive meditation on the need to adjust and re-tool one's vision according to the new temporality of timelapse pictures.

The second section of the film is highly self-reflexive in its use of technology to mold the movements of the plants. On the one hand, the intertitles evoke a highly emotive and almost expressionist language of primitive rhythms and animalistic desire, which could also be used to characterize the rhythm of Ausdruckstanz itself: "Urgewalt" (primal force), "sich kramphaft bewegend" (with a cramped movement), "verzweifelt" (desperate), "kämpfend" (struggling). On the other hand, the plants seem to be a caricature of industrial efficiency: exhibiting "iron energy," an impressive work ethic, speed ("blitzschnell"), and an ability to work in tandem ("Gleichtakt"). Although this second act of the film contains numerous intertitles, outlining plant species or genus (both popular and scientific names, including the Bananenblatt, Sichelfarn, Ranke, Medeola, Kletterpflanze), or describing plant motives and emotions, subsequent acts do not rely on intertitles to interpret or classify plant movement. In this second section of the film, which privileges a laboratory setting and the interfering hand of the operator, organic plant rhythm is depicted as a quivering psychology and also read through the lens of technologies of navigation and magnetoception: "As if on invisible command, the roots, like an undeterrable compass needle, follow the secret gravity." Time-lapse footage of tobacco plants is also accompanied by the didactic intertitle: "On strict common stride (Gleichtakt) the tobacco plants grow." As Michael Cowan writes in an essay on rhythm and the body in Weimar film, Weimar cultural critics such as Ludwig Klages understood Takt to be a rational and artificial ordering, "the staccato movement of clocks, metronomes, and pendulums," in opposition to "rhythm," understood to be an organic flow, likened to the flux of "becoming" that characterizes Bergsonian durée. Despite the absence of clocks in the time-lapse footage itself, the use of the term Takt in 
the Blumenwunder intertitles serves as a self-reflexive reminder of this technological need to measure, enabling the camera to illuminate the plant's own heliotropic processes. The term Takt on the one hand, recalls the industrialist military march, yet it also gives vitalist processes a new agency; plant rhythm speaks through the tap of time-lapse, "the machinic Takt of modernity."

One could argue that the "Gleichtakt" of the tobacco plants moving in unison also simultaneously serves to remind us of the Ausdruckstanz's "communal choir" or nature working in unison; it is clear that this plant choreography is not a Taylorized, mechanized "mass ornament," but has a keen will and a power of its own. As this section of the film continues, an "obstacle course" is set out for the plants; the intertitles gloss this mechanical interference, dramatizing the battle between organic "primitive force" and human "raw violence." Selfreflexively inscribing technology into the mise-en-scène, the intertitles highlight both organic processes and technological control as violent acts. The human attempt to influence plant growth through technological means is presented as "raw violence," whereas the plant's heliotropic striving to move upward toward the light is praised as "primitive." Although the language used to describe the will of the plant and its strivings, as well as the human power to shape its movement, has expressionist resonances, in this section of the film interpretive dance choreography is noticeably absent. Instead of the emotive gestures of Ausdruckstanz, here the hand of the scientist interrupts the scene as objective interference, in an attempt to redirect or hinder plant movement. There is no human "mimicry" or "mirroring" of plant pathos; rather, the human hand interferes with plant growth and the two agents, human-controlled technology and nature, enter into a "race": "But the human being attempts to force a leftward turn onto the plant with violence." In this "obstacle race," plants predominantly prevail (even while scientific prowess, such as a rotating drum, is put on display), although there are moments of sorrow, when plants existentially grope into "nothingness," finding no anchor for further growth. The dialectical antithesis of the lithe hand of interpretive dance, which extends from the interior (or Innenwelt) and is supposed to express inner feelings - the disembodied hand of the scientist serves as a sudden, external intrusion.

The film's modernist aesthetic is fulfilled, however, in the third, fourth and fifth acts, as the fantasy of marching and racing (self-reflexive play on mechanical rhythm) is obscured and Ausdruckstanz choreography again takes center stage.

44. Michael Cowan, “The Heart Machine: 'Rhythm' and Body in Weimar Film and Fritz Lang’s Metropolis," Modernism/modernity, vol. 14, n², April 2007, p. 231. 

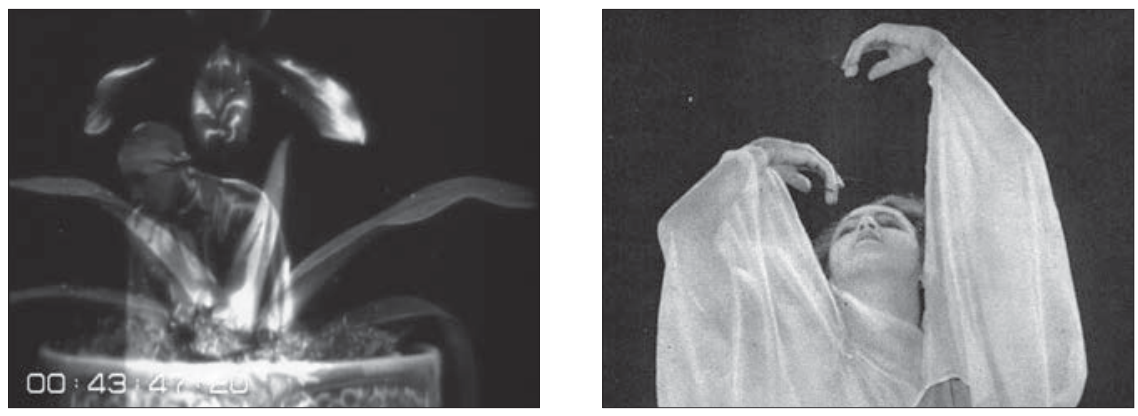

Fig. 5: Max Terpis, Plant Dissolve. Das Blumenwunder (Bundesarchiv-Filmarchiv).

Fig. 6: Stefa Kraljewa "Opium.” Das Blumenwunder (Bundesarchiv-Filmarchiv).

100 Lyrical dissolves from time-lapse footage into interpretive and modern dance serve to visualize and dramatize the "minor rhythm" (Dulac) of the plant's psychology (Fig. 5). It is worth noting, in closing, how closely these performances were to current developments on the German stage. The film's fairy tale frame narrative and interpretive dance sequences featured actors who had also performed on the Max Reinhardt stage and had trained in the Mary Wigman style of expressionist dance. ${ }^{45}$ Daisy Spies (a choreographer and dance instructor at the Mary Wigman School of Dance who had a very successful run in Oskar Schlemmer's "Triadic Ballet") and Elisabeth Grube had already collaborated in the Berlin Ballet Corps of the Prussian State Opera. The interpretive dance performances of Daisy Spies and Stefa Kraljewa in the film mime the plants "Opium" and "Hyacinth" (Fig. 6). Max Terpis, a former student of Laban and director of the Ballet Corps, is also prominently featured in the film in a highly abstract number. Blumenwunder thus gives us a unique blueprint of interpretive dance's aesthetic Zeitgeist under Terpis' leadership. Emblematic in this regard is a group performance of Terpis' Berlin ballet corps, shot initially from a highangle perspective and finally in slow-motion. What is striking about this number is how the dancers' fluid spontaneity gradually gives way to a lack of symmetry and heaviness, as female bodies move barefoot and in slow motion (finally even

45. In Breslau the film debuted on the $4^{\text {th }}$ of June, 1926 at the Konzerthauslichtspiele. The screening of Das Blumenwunder-touted as a Lehrfilm - was followed by a concert hall performance of Ursel-Renate Hirt's dance phantasies, Tanzphantasien. Hirt's dances aimed to bring to life Romantic nature poetry by Goethe and Felix Dahn, set to music by composers Strauss, Poldini and Gounod. The three acts of her dance stimulated spectators to explore the complexity of the plant-psyche, plant beauty and plant humor (I. "Die Seele der Blume," II. "Die Schönheit der Blume," and III. "Der Humor der Blume"). 
flexing muscles and showing underarm hair), evoking the danseur in René Clair's Entracte (1924) (Fig. 7).

Interestingly, the accusations voiced by educational critics regarding the film's "forced and unnatural dances" ("above all by ugly people") already anticipate the criticism of the Berlin State Opera Ballet under Terpis' direction. Terpis, however, around 1932 also claimed "ugliness" as part of his own aesthetic, arguing that modern dance could no longer be mimetically tied to beauty:

Our time has an outspoken inclination toward exaggeration, consumption; it loves the loud, the screaming, the extreme [...]. The dance programs consist largely of grotesques, parodies, problematic spiritual distortions, insofar as they do not exhibit artistic or virtuoso formalisms... It is rarely that one can identify a dance as "beautiful" or "elegant," rarely that a dance displays internally or externally an aristocratic bearing. Today we are immediately ready to identify everything that is "beautiful" and poetic - that is, harmonic - as kitsch. The ugly, unharmonic, unlogical strike us as interesting. ${ }^{46}$

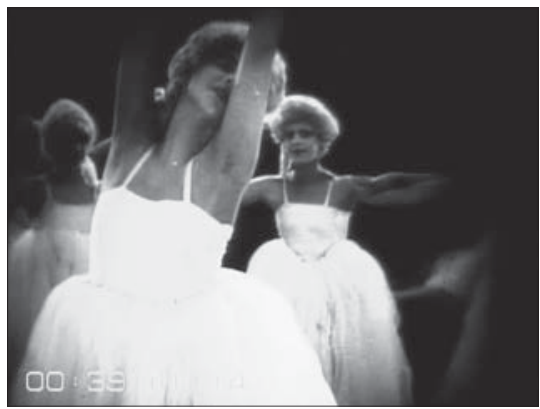

Fig. 7: Berlin Ballet Corps. Das Blumenwunder (Bundesarchiv-Filmarchiv).

Here we should recall that during the Weimar period, Ausdruckstanz, also called "expressionist," "interpretive," "absolute" or "ecstatic" dance, was an experimental dance form which aimed to "project deeper levels of the human psyche," ${ }^{\text {"47 }}$ but also chart out the "ugliness" and distorted rhythms of modern life.

46. As cited in Karl Toepfer, Empire of Ecstasy: Nudity and Movement in German Body Culture, 1910-1935, Los Angeles, Berkeley and London, University of California Press, 1997, p. 101-102.

47. Nancy Reynolds and Malcolm McCormick, No Fixed Points: Dance in the Twentieth-Century, New Haven and London, Yale University Press, 2003, p. 78. 
One of its key leaders, Rudolf Laban, trained dancers in an improvisational class to work in "Bewegungschören" (movement choirs), utilizing movements such as "common swinging and leaping, in measured, slow stepping or sprightly walking and running." ${ }^{\prime 8}$ His notational system of written dance (Schrifttanz) led to a system called Labanotation, what Laban envisioned as a universal script for dance, which could "record in its entirety any human action-sport, everyday activities, work, and scientific study, as well as dance."${ }^{149}$ In his notational system, a movement's path, as well as its rhythmic, spatial and dynamic factors were analyzed. Although Laban briefly served as the "director of movement" for Germany under Hitler (a post that fell under the supervision of the Nazi Ministry of Propaganda), his free dance was later censored by Goebbels and his schools and books declared “un-German." Laban's notational system, however, was not forgotten. During World War II, Laban's Ausdruckstanz itself became synonymous with machinic Takt, appropriated for the industrial age. At this time, Laban worked in Britain as an industrial consultant for the British government, "applying his system of movement analysis and notation to the energy expenditure of factory workers. ${ }^{\text {50 }}$ By analyzing the ratio of effort to accomplishment in their movements, Laban was able to suggest ways to "maximize efficiency." With a co-worker, Warren Lamb, he developed a system to capture the "qualitative aspects of movement, expressed by sixteen new symbols complementary to Labanization, which he called 'Effort-Shape." "51 Laban's inspired Ausdruckstanz gives way to a taylorized work-efficiency.

Other case studies of interpretive dance indicate that it was clearly in tune with technological rhythms. If Blumenwunder's choreography echoed the life rhythms of the natural world, other interpretive dances of the Weimar period mimicked machinic modernity, even motion picture technology itself. For example, many of Valeska Gert's expressionist dances are a parody of the modern metropolis. In her piece "Verkehr" (performed in 1926, the same year as Blumenwunder), Gert "extracted scenes from Berlin traffic-cars, policemen, accidents neon signs and traffic jams-in a reductionist manner," and in another 1926 piece provocatively entitled "Kino," she parodied the hand-cranking cinematic operator and the art of projection..$^{52}$ As Gert writes in her autobiography,

48. Ibid., p. 82.

49. Ibid., p. 84 .

50. Ibid.

51. Ibid.

52. Alexandra Kolb, Performing Femininity: Dance and Literature in German Modernism, Bern, Peter Lang, 2009, p. 183 . Also see Susanne Foellmer, Valeska Gerte: Fragmente 
in "Kino" she caricatured the disjointed stuttering of the silent screen: "These movements were flickering so that they looked shaky." ${ }^{\prime 3}$ Re-appropriating motion picture technology, she not only points to moments of flickering nervousness within the apparatus itself, her body becomes a "profane illumination" in the Benjaminian sense of a cinematic repetition of modernity's shocks and distracted rhythms.

In Blumenwunder, the bodies of the interpretive dancers ecstatically reproduce another nervousness of modernity, not industrial agitation, but the primitive angst and excitability of the plant, seen through the miraculous window of the cinematic Wunderlampe (Aladdin's lamp). In a never-ending play of awakening and repetition, the plant films elicit a mimetic response from spectators, transforming spectators into performers. Just as Gert's dances, through repetition, can be seen as cathartic reconciliation of man and machine, Blumenwunder's modern choreography mimetically "re-animates" and reconciles, inviting the human to participate in circadian ebbs and flows. As the reception of Blumenwunder indicates, modern dance choreography ${ }^{54}$ and time-lapse are said to animate, "give voice, laughter and tears" (Dulac), as well as illuminate the hitherto unseen interior. ${ }^{55}$

einer Avantgardistin in Tanz und Schauspiel der 1920er Jahre, Bielefeld, Transcript, 2006. In the late 1920s, Gert parodied emotional conditions, such as "nervousness," "pleasurable despair," and "tragic sorrow."

53. Valeska Gert, Mein Weg, Leipzig, A. F. Devrient, 1931, p. 40.

54. Blumenwunder was not the only film of the 1920 s to create a fluid dissolve between modernist choreography and plant temporality. The French surrealist Jean Painlevé also compared underwater plant movement to Loïe Fuller's art nouveau Serpentine dance or "ballet" in Hyas et Sténorinques (Hyas and Stenorhynchus, 1929) and Germaine Dulac in Thèmes et Variations (1928) superimposed machinic movement, plant movement and dancing in a cinematic ballet of "visual affect."

55. I would like to thank Michael Cowan, Gustav Deutsch and the participants of a workshop on industrial filmmaking at McGill University for offering valuable comments on an earlier version of this paper. I am also indebted to Michael Cowan, Phillipe Despoix and anonymous reviewers for their insightful comments and constructive criticism of this essay. 